\title{
UNCONFINED AQUIFER PERMEABILITY NEAR HAND-DUG WELLS IN THE COASTAL AND INTERIOR DRYLAND OF THE LIBERTADOR GENERAL BERNARDO O'HIGGINS REGION, CHILE
}

\author{
David E. Rupp ${ }^{1 *}$, Oscar Reckmann², Jorge Vergara ${ }^{3}$, Hamil Uribe ${ }^{4}$, and John S. Selker ${ }^{5}$
}

\begin{abstract}
In the dryland of the Libertador General Bernardo O'Higgins Region in Chile, most farmers rely on wide and shallow hand-dug wells as their primary source of water during the dry summer. Few of these wells have sufficient yield for more than domestic use (human consumption, livestock, and irrigation of a subsistence garden). To more accurately assess available groundwater resources, saturated hydraulic conductivity $(K)$ of aquifers in the eight counties that comprise this region's dryland was estimated using evacuation and recovery tests in 353 hand-dug wells. $K$ followed a log-normal distribution and ranged over nearly five orders of magnitude. County median $K$ varied by a factor of 5 and a slight increasing $K$ trend in the southward direction. In one northern county, less than $4 \%$ of the sites had $K>4 \mathrm{~m} \mathrm{~d}^{-1}$. In the t two southernmost counties, approximately one-quarter of the $K$ values exceeded $4 \mathrm{~m} \mathrm{~d}^{-1}$. This is approximately the minimum $K$ required for a typical well ( $1 \mathrm{~m}$ diameter and $3 \mathrm{~m}$ depth below the water table) to yield $1 \mathrm{~L} \mathrm{~s}^{-1}$ of water, which is roughly the yield required to irrigate 1 ha. Aquifers located where parent material was predominantly intrusive granite had slightly higher and statistically significant $K$ than those formed predominantly of metamorphic and sedimentary rock. A semi-variogram of $K$ provided weak evidence of a characteristic length scale of approximately $4 \mathrm{~km}$.
\end{abstract}

Key words: Groundwater, well recovery, slug-test.

$\mathrm{T}$ he Secano, or dryland, of the Libertador General Bernardo O'Higgins Region in Chile is located in the coastal range and is bounded by the Pacific Ocean to the west and the central depression to the east (Figure 1). As the name Secano implies, it experiences periods of dryness and is considered arid for 5 to 6 mo of the year (Ovalle, 1994). Most small farmers in the dryland of this region of Chile rely on wide and shallow handdug wells, which penetrate only the unconfined aquifer, as their primary water source. Few of these wells presently have sufficient yield for more than domestic and livestock

${ }^{1}$ Oregon State University, Cooperative Institute for Marine Resources Studies, Newport, Oregon, 97365, USA.

*Corresponding author (david.rupp@oregonstate.edu).

${ }^{2}$ Instituto de Investigaciones Agropecuarias INIA, Carrera $\mathrm{s} / \mathrm{n}$, Marchigüe, Chile.

${ }^{3}$ Universidad de Chile, Facultad de Ciencias Agronómicas, Av. Santa Rosa 11.315, La Pintana, Santiago, Chile.

${ }^{4}$ Instituto de Investigaciones Agropecuarias INIA, Casilla 426, Chillán, Chile.

${ }^{5}$ Oregon State University, Department of Biological and Ecological Engineering, Corvallis, Oregon, 97331, USA.

Received: 13 September 2010.

Accepted: 17 February 2011.

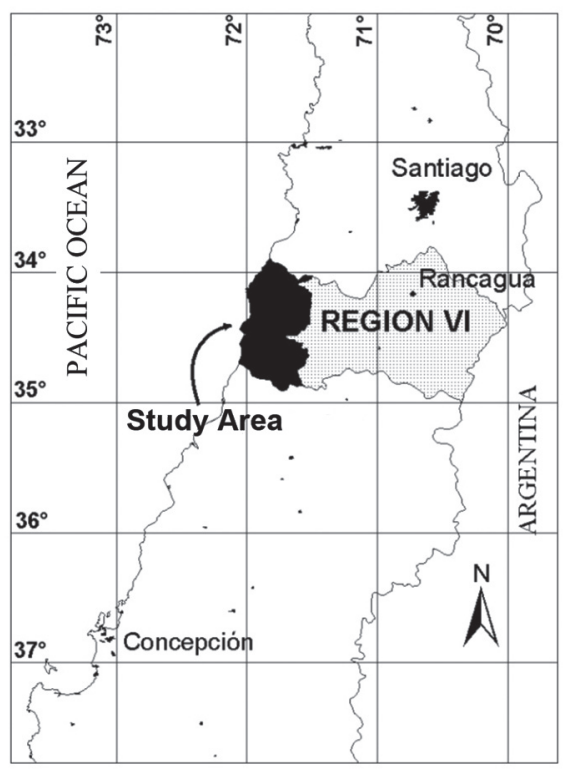

Figure 1. Counties (shaded in black) that comprise the dryland, or Secano, of the Libertador General Bernardo O'Higgins Region in Chile (shaded in gray). 
use and to irrigate a subsistence garden during the dry summer period.

This part of the dryland, with the exception of some Quaternary unconsolidated fluvial deposits and sediments, is considered to have "zero to very low hydrological importance" (DGA, 1986; 1991). In general, its geology is primarily intrusive granitic and metamorphic rock thought to be essentially impermeable, as well as mixed sedimentary and volcanic rock with a very low permeability (SERNAGEOMIN, 1982; DGA, 1986; 1991) (Figure 2 and Table 1).

However, this hydrogeological assessment conducted as a nation-wide survey was based on very few wells

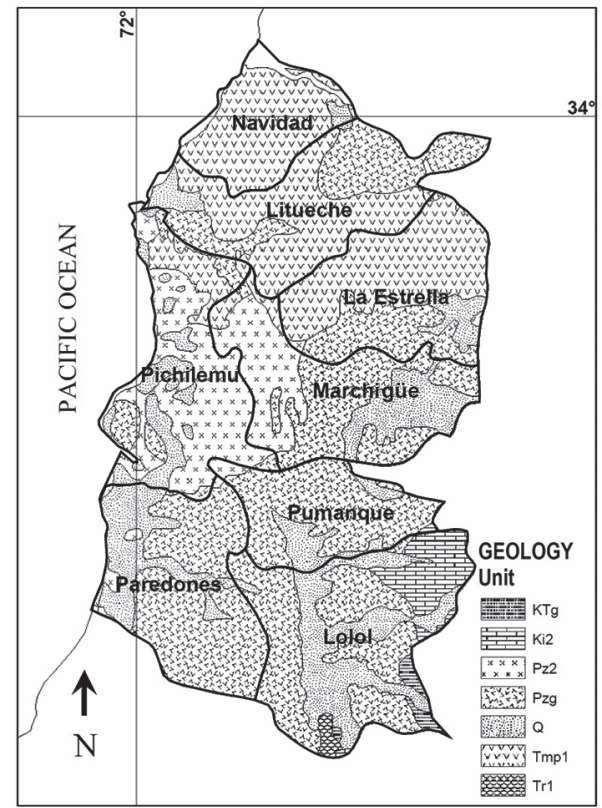

Figure 2. Geology of eight counties that comprise the dryland of the Libertador General Bernardo O'Higgins Region in Chile. See Table 1 for a description of the geological units. Adapted from SERNAGEOMIN (2003). in our study area, and disagrees with the occurrence of scattered wells in this area with sufficient characteristics for small irrigation projects. In order to more accurately quantify available groundwater resources, we estimated the saturated hydraulic conductivity $(K)$ of the aquifer material surrounding hundreds of wells in this region's dryland. Since $K$ is the primary control of a well's ability to deliver water in an unconfined aquifer, along with well dimension, knowing $K$ gives us way to evaluate aquifer potential to deliver water over and above the yield when the well was tested.

We begin this paper with a discussion of the analytical method used to estimate $K$, which is specific to wide and shallow wells and may be new to readers. The results are analyzed by county and also by geologic parent material for data subsets to find broad geographic differences in aquifer permeability. We also explore the relationship between inter-well variability as a function of proximity for a data subset. Although geostatistical studies of aquifer $K$ using moderate to large sample sizes have been done elsewhere in the world at field lengths ranging from meters to tens of kilometers (Sudicky, 1986; Bjerg et al., 1992; Rehfeldt et al., 1992; Eggleston et al., 1996; Mas-Pla et al., 1997; Eggleston and Rojstaczer, 1998; Sudicky et al., 2010), published datasets and analyses are infrequent in Chile (e.g., Rojas et al., 2010) and non-existent in the dryland region. We finish with a brief discussion of the potential for unconfined aquifers in the region to yield sufficient water for irrigation.

\section{MATERIALS AND METHODS}

Evacuation and recovery tests were carried out on 353 existing large-diameter, hand-dug wells in eight counties that make up the Secano Interior (interior dryland) and Secano Costero (coastal dryland) of the Libertador General Bernardo O'Higgins Region in Chile. Almost all of the tests were carried out during the dry summer months, December through February 2000, although a

Table 1. Geological units in the dryland of the Libertador General Bernardo O'Higgins Region.

\begin{tabular}{lcl}
\hline Units & \% Area & \multicolumn{1}{c}{ Description } \\
\hline Pzg & 41 & $\begin{array}{l}\text { Paleozoic: plutonic and hypabbysal rock. } \\
\text { Miocene-Pliocene: sandstone, calcareous sandstone, limestone, conglomerate, and } \\
\text { Tmp1 }\end{array}$ \\
$\begin{array}{l}\text { limolites with marine fossils. } \\
\text { Quaternary: fluvial, lake, glacial, wind, alluvial, colluvial, and lahar sediments. }\end{array}$ \\
P & 18 & $\begin{array}{l}\text { Paleozoic: metamorphic sandstones, slate, phyllite, shale, serpentine, gneiss, and } \\
\text { amphibolites. }\end{array}$ \\
Ki2 & 12 & $\begin{array}{l}\text { Lower Cretaceous: andesitic, dacitic, rhyolitic flows and breccias; trachytic tuffs and } \\
\text { ignimbrites; interbedded sediments. } \\
\text { KTg: plutonic and hypabbysal rock; Tr1: sedimentary and/or volcanic rock; lakes; other. }\end{array}$ \\
Other & 2 &
\end{tabular}


small number (six) were conducted during subsequent summers. Well dimensions and depth to water level were recorded prior to each test. The choice of wells was mainly based on accessibility and owner cooperation. A spatial sampling design was not considered because the initial objective of well testing was not a rigorous spatial analysis. The dataset contains geographic coordinates collected with a global positioning system for 192 of the 353 wells.

Saturated hydraulic conductivity $(K)$ of the aquifer surrounding each well was estimated from the time required for the water level in a well to recover $75 \%$ of its original level after being nearly emptied (Figure 3). We assumed recovery tests were equivalent to slug tests because the pumping period $t_{p}$ to lower the water level was short as compared to the recovery period. The error incurred from this assumption should be less than $10 \%$ if $t_{p}<4 r^{2} / T$ where $r$ is the well radius and $T$ is transmissivity (Mace, 1999). Thus, for a realistic example of a well dug to a hard or rocky bottom of an aquifer of depth $L$ such that $T=K L$ and where $K=1 \mathrm{~m} \mathrm{~d}^{-1}, L=2 \mathrm{~m}$, and $r=0.5$ $\mathrm{m}$, the pumping period $t_{p}$ should be less than $12 \mathrm{~h}$, which is certainly manageable even with a common pump.

Slug-test analysis was based on Rupp et al. (2001) who modified the commonly-used Bouwer and Rice (1976) method so that it would be better suited to shallow, large-diameter wells. The method requires plotting the recovery curve as $\ln (y)$ vs. $t$ where $y$ is the drawdown in the well, and identifying the slope where the relationship is approximately linear. However, since the goal of this study was to test a very large number of wells over a large area in a relatively short time without access to automated water level recorders, we only recorded time $t_{0}$ and drawdown $y_{0}$ when pumping ceased and time $t_{75}$ when the water level had returned to approximately $75 \%\left(y_{75}\right)$ of its original position before drawdown. We calculated $K$ from:

$$
K=\frac{r^{2} \ln \left(R_{e} / r\right)}{2 L\left(t_{75}-t_{0}\right)} \operatorname{In}\left(\frac{y_{0}}{y_{75}}\right)
$$

where $R_{e}$ is the effective radius and can be estimated from:

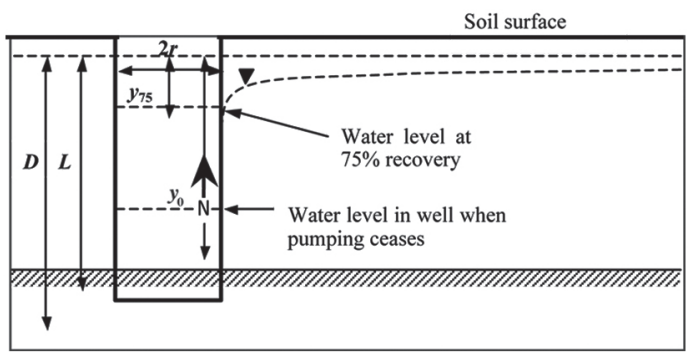

Figure 3. Schematic of a large-diameter well in an unconfined aquifer.

$$
\ln \left(\frac{R_{e}}{r}\right)=\frac{C_{1}+C_{2} \ln \left[\Lambda(L / r)^{2}\right]}{1+C_{3}[(D-L) / D]^{1 / 2}(L / r)^{-5 / 8}}
$$

where $\Lambda$ is a measure of soil capillarity and $C_{1}, C_{2}$, and $C_{3}$ are constants. For units in meters, $C_{1}=1.839$, $C_{2}=0.209$, and $C_{3}=1.614$. The capillarity parameter $\Lambda$ is a function of water retention of the aquifer material and can be estimated from texture (Rupp et al., 2001). Without specific soil information for each well location, we assumed a value of $\Lambda=10 \mathrm{~m}$ for all sites, which is appropriate for a silty loam or clay loam. Given that each case of aquifer depth $D$ was unknown, or at best poorlydefined, we calculated $K$ for the two limiting cases of $D=$ $L$ and $D=\infty$ and reported their mean. Fifty-one, or about one-sixth, of the wells had rectangular cross-sections. Although Equations [1] and [2] assume a circular well, we substituted the expression $(w l / \pi)^{1 / 2}$ for the radius $r$ where $w$ and $l$ are the horizontal dimensions of the rectangular well.

Frequency distributions of $K$, in addition to general statistics, were calculated for each county and for all counties as a whole. Frequency distributions were also generated by geological formation for a well subset with available geographic coordinates $(n=192)$. Information on the geological parent material was extracted from the 1:1000 000 digitized national geologic map (SERNAGEOMIN, 2003). $K$ distributions were compared and considered along with general geological characteristics of each county. Lastly, spatial correlation in $K$ was analyzed to see if a characteristic correlation length scale could be identified. This was done by computing the empirical semi-variogram with the classical semivariogram estimator $\gamma(h)$ where $h$ is the lag, or distance, between measurements, as well as fitting an exponential model to the semi-variogram to estimate range (e.g., Sudicky et al., 2010).

\section{RESULTS}

Well dimensions included a wide array of sizes and depths and indicated highly variable conditions. Circular wells had diameters ranging from 0.9 to $6.0 \mathrm{~m}$. Rectangular wells ranged in size from $0.7 \times 0.8 \mathrm{~m}$ to $4.7 \times 6.0 \mathrm{~m}$, although there was a notably long one of $3.0 \times 9.0 \mathrm{~m}$. The mean radius, including the equivalent radius of the rectangular wells, was $1.8 \mathrm{~m}$. Well depths varied between 0.3 and $14.9 \mathrm{~m}$ with a mean of $5.9 \mathrm{~m}$. Water depth in each well also varied considerably $(0.3$ to $10.0 \mathrm{~m})$. The water table ranged from being essentially at the surface down to $9.8 \mathrm{~m}$ below the surface, averaging $3.3 \mathrm{~m}$. However, the distribution was skewed with a peak frequency at approximately $1.8 \mathrm{~m}$. 
Values of $K$ varied by nearly five orders of magnitude $\left(0.002\right.$ to $\left.90 \mathrm{~m} \mathrm{~d}^{-1}\right)$ and were highly skewed with the frequency distribution most usefully viewed on a logarithmic scale (Figure 4). Since the log-normal distribution fits many observed distributions of $K$ (Domenico and Schwartz, 1990), we did a test of normality (Filliben, 1975) on the log-transformed values of $K$. Based on the correlation coefficient $(\mathrm{r}=0.9936)$ of the normal probability plot of log-transformed $K$, we found that there would be a high percentage of incorrectness $(>75 \%)$ if we rejected the hypothesis that $K$ is log-normally distributed.

Ninety-eight percent of the 192 wells with geographic coordinates are located in the three dominant geological units: Pzg (predominately intrusive granite), Tmp1 (predominantly metamorphic and sedimentary rock), and Q (predominantly unconsolidated sediment). Frequency distributions of $K$ show a slightly higher $K$ for the unconfined aquifers in unit Pzg than in unit Tmp1 and aquifers in unit $\mathrm{Q}$ falling somewhere in between (Figure 5). It is suggested that the geometric mean describes the "average" conductivity of an aquifer better than other statistical means (Domenico and Schwartz, 1990), so we chose it as the statistical measure with which to compare distributions of $K$ between geological units (and between counties). The geometric mean can be found by taking the exponent of the mean of the natural $\log (\ln )$ of $K$ (Fetter, 1994). The geometric means of $K$ per unit range from 0.40 $\mathrm{m} \mathrm{d}^{-1}$ in $\mathrm{Q}$ to $0.96 \mathrm{~m} \mathrm{~d}^{-1}$ in Pzg (Table 2). The means of ln $K$ were significantly different between Tmp1 (-0.91) and Pzg (-0.04) at the 0.1 level using the Bonferroni method for multiple comparisons, but not so when using the Tukey Honestly Significant Difference (HSD) test (Devore, 1987). No other pair-wise comparisons showed significant differences.

It is interesting that while unit Tmp1 is given "very low" hydrogeological importance and unit Pzg is given "zero" hydrogeological importance, we found the unconfined

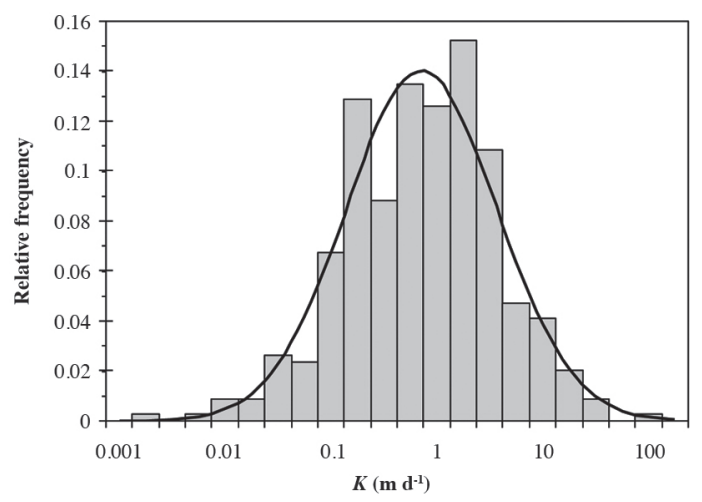

Figure 4. Relative frequency distribution of saturated hydraulic conductivity $(K)$ from all wells with fitted log-normal distribution.
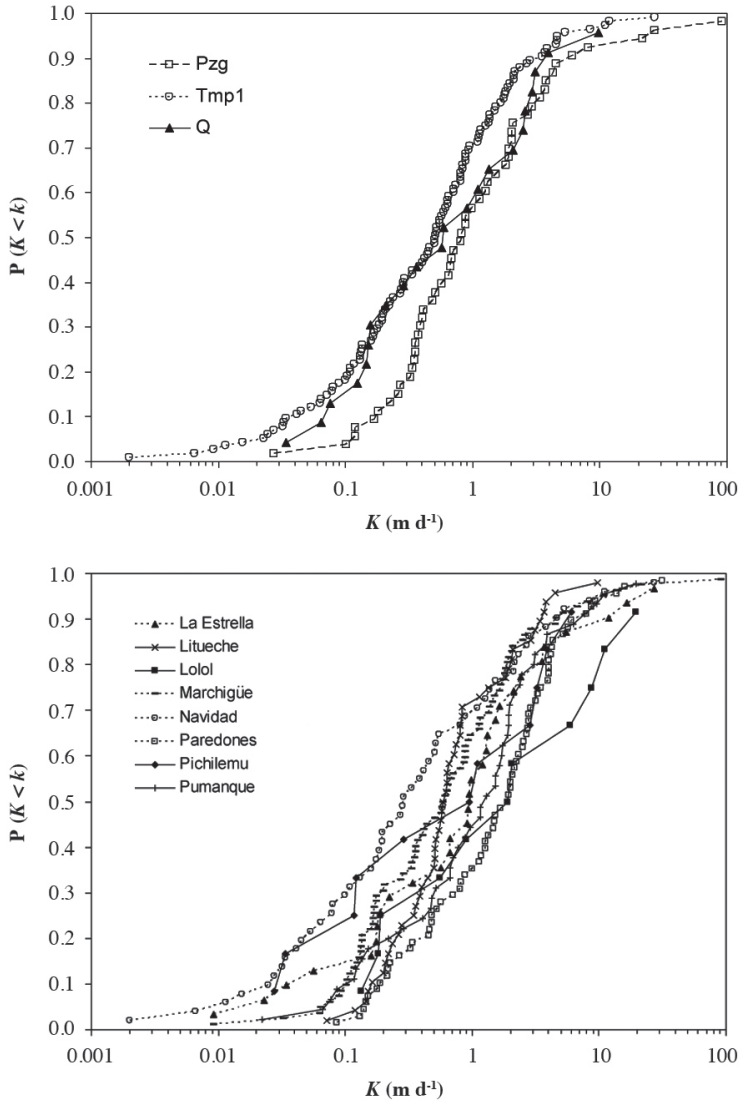

Figure 5. Cumulative relative frequency of saturated hydraulic conductivity $(K)$ for each geological unit (upper plot) and county (lower plot).

aquifers in Tmp1 to be slightly more permeable than those in Pzg. However, the geometric means of $K$ between the two units only vary by a factor of approximately two (Table 2), which is very small compared to the total range of $K$ values (nearly five orders in magnitude) (Figure 5).

The values of $K$ that we estimated for wells located in areas mapped as unconsolidated sediments (unit Q) are particularly noteworthy since they were not higher than the values for the other geological units, although these unconsolidated sediments are designated as having "medium to high" geological importance. Given current data, we can only speculate as to the cause. It is possible that these wells are not actually located in aquifers composed of unconsolidated sediments and that misclassification is a result of the coarse scale with which geological formations have been mapped.

Variability in $K$ among counties is evident from the cumulative frequency distributions of $K$ (Figure 5). The northernmost county, Navidad, shows the least permeability (median $=0.29 \mathrm{~m} \mathrm{~d}^{-1}$ ), while distributions of the two southernmost counties of Paredones and Lolol have a right-shift factor of $6.6\left(\right.$ median $\left.=1.92 \mathrm{~m} \mathrm{~d}^{-1}\right)$. The 
Table 2. Summary statistics of $K\left(\mathrm{~m} \mathrm{~d}^{-1}\right)$ for each geological unit.

\begin{tabular}{|c|c|c|c|c|c|c|c|}
\hline $\begin{array}{l}\text { Geological } \\
\text { units }^{1}\end{array}$ & $n$ & Mean $\ln K$ & $S D \ln K$ & $\begin{array}{c}\text { Geometric } \\
\text { mean } K\end{array}$ & Mean $K$ & SD $K$ & $\begin{array}{c}\% K>4 \\
m^{-1}\end{array}$ \\
\hline Pz2 & 4 & 0.02 & 1.52 & 1.02 & 1.80 & 1.51 & 0 \\
\hline Pzg & 52 & -0.04 & 1.49 & 0.96 & 4.03 & 13.18 & 13 \\
\hline Tmp1 & 114 & -0.91 & 1.69 & 0.56 & 1.50 & 2.18 & $<1$ \\
\hline Q & 22 & -0.57 & 1.56 & 0.40 & 1.35 & 3.10 & 7 \\
\hline All & 192 & -0.62 & 1.65 & 0.54 & 2.11 & 7.37 & 8 \\
\hline
\end{tabular}

${ }^{1}$ Geological units defined in Table 1 .

remaining counties generally fall between these lower and upper envelopes.

County geometric means range from $0.3 \mathrm{~m} \mathrm{~d}^{-1}$ (Navidad) to $1.5 \mathrm{~m} \mathrm{~d}^{-1}$ (Lolol), a factor of 5 (Table 3). Mean ln $K$ for Navidad (-1.19) differed significantly from both Paredones (0.34) and Pumanque (-0.05) at the 0.1 level using the Bonferroni method for multiple comparisons, while Navidad differed significantly from Paredones using the Tukey HSD test. No other pair-wise comparisons showed significant differences. However, we are not able to detect statistically significant differences among other counties because of the small sample size for Lolol and Pichilemu $(n=11)$. On the whole, there appears to be a general spatial pattern of increasing $K$ from North to South (Figure 6), with regard to the area's geology.

In a sense, the northernmost county, Navidad, is the most geologically homogeneous and dominated by Triassic metamorphic and sedimentary rock (Figure 2, Tables 1 and 4). The hydrogeological importance of this formation has been categorized as "very low" (DGA, 1991). This formation also includes over half of the Litueche and $\mathrm{La}$ Estrella counties. The rest of these two counties is mostly made up of Paleozoic plutonics (intrusive granite) of relatively "zero" hydrogeological importance, although both have a small amount of unconsolidated Quaternary sedimentary deposits (5 to $8 \%$ ). Continuing South,
Pichilemu and Marchigüe counties are more geologically diverse (Figure 2), but except for the unconsolidated Quaternary deposits that make up approximately $20 \%$

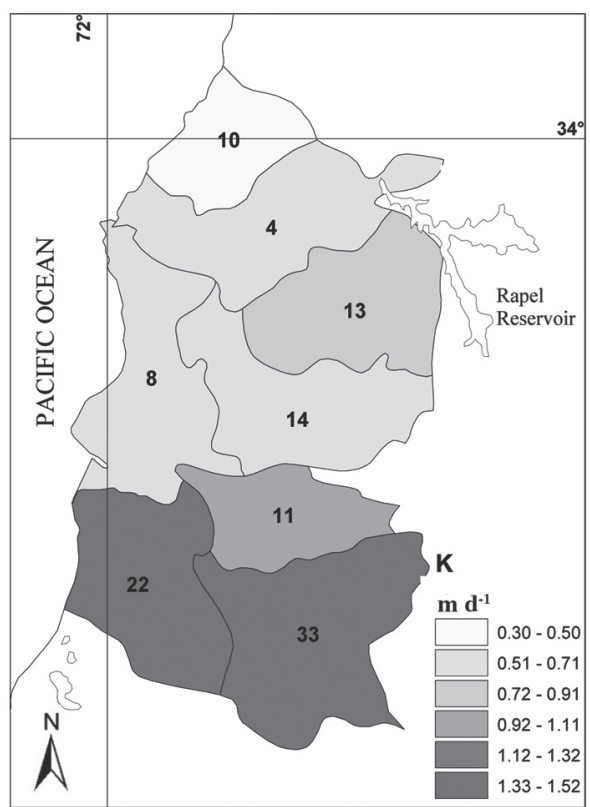

Figure 6. Saturated hydraulic conductivity $(K)$ by county. Shading represents geometric mean of $K$. The number in each county is the percentage of locations (wells) where $K>4 \mathrm{~m} \mathrm{~d}^{-1}$.

Table 3. Summary statistics of saturated hydraulic conductivity $(K)\left(\mathrm{m} \mathrm{d}^{-1}\right)$ for each county.

\begin{tabular}{lcrcccccc}
\hline County & $\boldsymbol{n}$ & $\boldsymbol{n}^{*}$ & Mean $\mathbf{l n} \boldsymbol{K}$ & SD $\mathbf{l n} \boldsymbol{K}$ & $\begin{array}{c}\text { Geometric } \\
\text { mean } \boldsymbol{K}\end{array}$ & Mean $\boldsymbol{K}$ & SD $\boldsymbol{K}$ & $\begin{array}{c}\boldsymbol{\%} \boldsymbol{K}>\mathbf{4} \\
\mathbf{m ~ d}^{-\mathbf{1}}\end{array}$ \\
\hline La Estrella & 30 & 13 & -0.32 & 1.88 & 0.72 & 2.90 & 5.81 & 13 \\
Litueche & 47 & 46 & -0.41 & 1.07 & 0.67 & 1.22 & 1.69 & 4 \\
Lolol & 11 & 0 & 0.42 & 1.78 & 1.52 & 1.22 & 6.25 & 33 \\
Marchigüe & 87 & 62 & -0.41 & 1.66 & 0.66 & 4.66 & 12.83 & 14 \\
Navidad & 50 & 50 & -1.19 & 2.03 & 0.30 & 3.68 & 4.24 & 10 \\
Paredones & 67 & 10 & 0.34 & 1.31 & 1.42 & 1.71 & 4.67 & 22 \\
Pichilemu & 11 & 11 & -0.64 & 1.95 & 0.53 & 3.01 & 2.03 & 8 \\
Pumanque & 44 & 0 & -0.05 & 1.50 & 0.95 & 1.70 & 3.61 & 11 \\
Total & 347 & 192 & -0.30 & 1.66 & 0.74 & 2.66 & 7.39 & 14 \\
\hline
\end{tabular}

*Number of wells with geographic coordinates. 
Table 4. Percentage area of geological unit for each county.

\begin{tabular}{|c|c|c|c|c|c|c|}
\hline \multirow[b]{2}{*}{ County } & \multicolumn{6}{|c|}{ Geological units ${ }^{1}$} \\
\hline & Pzg & Tmp1 & $\mathbf{Q}$ & Pz2 & $\mathbf{K i} 2$ & Other \\
\hline La Estrella & 29 & 62 & 8 & 1 & 0 & 0 \\
\hline Litueche & 38 & 56 & 5 & 0 & 0 & 1 \\
\hline Lolol & 48 & 0 & 32 & 0 & 16 & 4 \\
\hline Marchigüe & 45 & 5 & 22 & 28 & 0 & 0 \\
\hline Navidad & 1 & 86 & 3 & 0 & 0 & 10 \\
\hline Paredones & 71 & 0 & 25 & 3 & 0 & 1 \\
\hline Pichilemu & 12 & 11 & 19 & 56 & 0 & 2 \\
\hline Pumanque & 79 & 0 & 17 & 3 & 1 & 0 \\
\hline
\end{tabular}

${ }^{1}$ Geological units defined in Table 1.

of each county, the remaining formations have "zero" hydrogeological importance. Further South, is Pumanque, a county that mainly consists of plutonic and hypabbysal rock and less unconsolidated sedimentary rock $(\sim 17 \%)$. The two southernmost counties, Paredones and Lolol, have the highest percentage of unconsolidated sedimentary deposits (25 and 32\%, respectively), although the dominant formation consists of intrusive granite in both cases.

This apparent general latitudinal trend in $K$ could be associated to geological changes from North to South. However, the trend in $K$ contrasts somewhat with DGA (Dirección General de Aguas, Santiago, Chile) definitions of hydrogeological importance, so that it is not clear if there is any practicality, for our purposes, in the distinction made by DGA (1991) between formations that have "zero" or "very low" hydrogeological importance. For example, while most of Navidad is classified as "very low", aquifers tested there were less conductive than those in Litueche and La Estrella, which were located in formations classified as "zero" and "very low", respectively. However, we understand that DGA may have considered the aquifer depth as well as conductivity when making their classifications.

One could assume that the proportion of unconsolidated sedimentary deposits explains much of the variation we see in $K$ among counties. However, the above analysis of $K$ based on geological formation does not support the assumption: $K$-values derived from well tests in areas mapped as Quaternary sediments are no higher than those found in the other geological formations. However, it is clear that farmers in the Lolol and Paredones counties have a much higher probability, geographically speaking, of having access to higher permeable unconsolidated sediments than farmers in Navidad where there is no significant amount of such aquifer material.

The large amount of scatter in the semi-variogram of $\ln K$ made it difficult to detect a range or characteristic

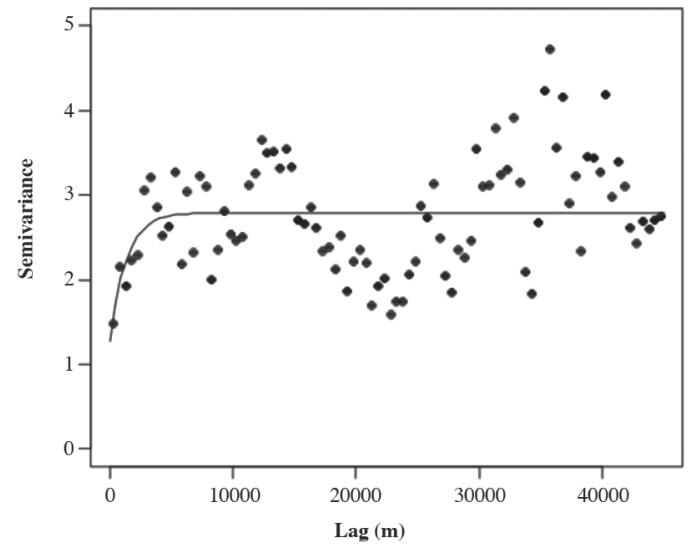

Figure 7. Empirical semi-variogram of $\ln K$ (solid circles) and fitted exponential model (solid line).

length scale (Figure 7). The semi-variogram indicates that while variability increases with distance up to a few kilometers, variances are equally low at distances of, for example, 21 to $24 \mathrm{~km}$ as they are at 1 to $3 \mathrm{~km}$. The fitted exponential model resulted in a practical range of $4.0 \mathrm{~km}$, thus implying that proximity might be useful in predicting aquifer permeability. However, our confidence in this particular range is low given the high variability in $\gamma$ in the fitted function. Even so, a correlation scale of $4 \mathrm{~km}$ is consistent with the observation by Neuman (1994) that a correlation scale is roughly one-tenth the field length for natural log conductivity.

\section{DISCUSSION}

A small farmer is going to dig a well on his property where he believes it possible to get the best yield with the least energy expenditure. This is likely to be where he believes the water table is relatively high, although he may take into account soil material. Distance from the home may also be a factor, or the farmer may rely on his, 
or another's, experience with a dowsing rod, also known as a divining rod. This proclivity of the farmer introduces bias into our sampling, so we acknowledge that the aquifers we analyzed are not representative of the entire area making up the eight counties, but represent those areas where farmers tend to locate wells.

Bearing this in mind, we want to examine the likelihood of achieving a yield sufficient for irrigation during the summer given our estimates of aquifer conductivity. Although it depends on the crop, soil, and local climate, a yield of $1 \mathrm{~L} \mathrm{~s}^{-1} \mathrm{ha}^{-1}$ in the dryland is often considered as a general minimum requirement for a well to be useful for irrigation by a small farmer. We can obtain a general estimate of the potential yield $Q$ for a given model well in an unconfined aquifer from Thiem's (1906) equation:

$$
Q=2 \pi K L \frac{y}{\ln \left(R_{e} / r\right)}
$$

Maximum $Q$ for a given well in an aquifer occurs when $L=y$. Note that Equation [3] does not refer to aquifer size, that is, the ability to sustain a given $Q$ over time, which may limit well productivity.

Most wide wells that are being dug in the dryland are approximately $1 \mathrm{~m}$ in diameter, which is a standard size for concrete tubing sections. These concrete cylinders, often perforated, are placed in the well for support. We will thus assume typical dimensions for our model well as $r=0.5 \mathrm{~m}$ and $L=3 \mathrm{~m}$. Equation [3] shows that since $Q$ is approximately proportional to the square of the depth of the aquifer penetrated, even a relatively small increase in depth will have a significant effect. On the other hand, because the radius falls within the logarithmic expression in Equation [3], one must greatly increase the radius to substantially increase the yield. Many of the wells studied did not fully penetrate the aquifers because the depth of hand-dug wells is often limited by the ability to avoid collapse and other difficulties of working below the phreatic surface. Thus, with the use of more advanced tools, the depth of many of these wells could be substantially increased.

\section{CONCLUSIONS}

From the observed frequency distributions of $K$, we estimate that $14 \%$ of analyzed aquifers are sufficiently permeable for irrigation purposes. Separated by county, these percentages range from a high of $33 \%$ in Lolol to a low of $4 \%$ in Litueche.

We see that in this part of the dryland there is geographical variability in unconfined aquifer permeability on a broad scale in addition to high variability on the more local scale (i.e., within counties). At smaller distances $(<$
$4 \mathrm{~km}$ ), proximity may also explain some of the variability in permeability; however, evidence of a particular correlation length scale was weak. However, the use of geological parent material mapped on the relatively coarse scale of the available geological map is not very useful to explain the unconfined aquifer conductivity observed where existing wells are located.

\section{ACKNOWLEDGEMENTS}

We thank the U.S. National Science Foundation for partial funding of this study; the Instituto de Investigaciones Agropecuarias INIA for providing logistical support and the data used in this study; Flavio Durán and Patricio Donoso for their assistance in field data collection and compilation; and anonymous reviewers for their comments and suggestions to improve an earlier draft of this paper.

\section{RESUMEN}

Permeabilidad de acuíferos no-confinados cerca de pozos norias en el Secano Costero e Interior, Región del Libertador General Bernardo O'Higgins, Chile. La mayoría de los agricultores del secano de la Región del Libertador General Bernardo O'Higgins depende de pozos noria, constituyendo su principal fuente de agua durante el verano. Pocos pozos tienen rendimiento suficiente para un uso mayor que el doméstico (consumo humano, ganadería y riego). A fin de evaluar con mayor precisión los recursos hídricos subterráneos disponibles, mediante pruebas de bombeo-recuperación se estimó la conductividad hidráulica saturada $(K)$ de los acuíferos en 353 pozos distribuidos en ocho comunas del área. $K$ siguió una distribución log-normal, con una $K$ máxima casi cinco órdenes de magnitud mayor que la mínima. La mediana de $K$ varió en un factor de 5 por comuna y tuvo una ligera tendencia creciente en dirección Sur. En una comuna del Norte, se estimó que menos del $4 \%$ de los sitios presentaron $K>4 \mathrm{~m} \mathrm{~d}^{-1}$. En dos comunas del Sur, alrededor del $25 \%$ de los valores de $K$ superaron los $4 \mathrm{~m} \mathrm{~d}^{-1}$, valor mínimo requerido para que un pozo de dimensiones típicas ( $1 \mathrm{~m}$ de diámetro y $3 \mathrm{~m}$ de profundidad bajo el nivel de agua) produzca $1 \mathrm{~L} \mathrm{~s}^{-1}$ de agua, suficiente para regar 1 ha. Los acuíferos localizados en áreas con material predominantemente granítico, tuvieron levemente mayores $\mathrm{K}$, estadísticamente significativos, que los formados predominantemente de rocas metamórficas y sedimentarias. El semi-variograma de $K$ indicó un rango de dependencia de $4 \mathrm{~km}$.

Palabras clave: aguas subterráneas, recuperación de pozos, slug-test. 


\section{LITERATURE CITED}

Bjerg, P.L., K. Hinsby, T.H. Christensen, and P. Gravesen. 1992. Spatial variability of hydraulic conductivity of an unconfined sandy aquifer determined by a mini slug test. Journal of Hydrology 136:107-122.

Bouwer, H., and R.C. Rice. 1976. A slug test for determining hydraulic conductivity of unconfined aquifers with completely or partially penetrating wells. Water Resources Research 12:423-428.

DGA. 1986. Mapa hidrogeológico de Chile. Dirección General de Aguas, Ministerio de Obras Públicas, Santiago, Chile.

DGA. 1991. Mapa hidrogeológico de Chile. Dirección General de Aguas, Ministerio de Obras Públicas, Santiago, Chile.

Devore, J.L. 1987. Probability and statistics for engineering and the sciences. Brooks/Cole Publishing Co., Monterey, California, USA.

Domenico, P.A., and F.W. Schwartz. 1990. Physical and chemical hydrogeology. 824 p. John Wiley and Sons, New York, USA.

Eggleston, J., S. Rojstaczer, and J. Peirce. 1996. Identification of hydraulic conductivity structure in sand and gravel aquifers: Cape Cod data set. Water Resources. Research 32:1209-1222.

Eggleston, J., and S. Rojstaczer. 1998. Identification of large-scale hydraulic conductivity trends and the influence of trends on contaminant transport, Water Resources Research 34:2155-2168, doi:10.1029/98WR01475.

Fetter, C.W. 1994. Applied hydrogeology. 691 p. Prentice Hall, Englewood Cliffs, New Jersey, USA.

Filliben, J.J. 1975. The probability plot correlation coefficient test for normality. Technometrics 17(1):111-117.

Mace, R.E. 1999. Estimation of hydraulic conductivity in large-diameter, hand-dug wells using slug-test methods. Journal of Hydrology 219:34-45.

Mas-Pla, J., T.-C. J. Yeh, T. M. Williams, and J.F. McCarthy. 1997. Analyses of slug tests and hydraulic conductivity variations in the near field of a two-well tracer experiment site. Ground Water 35:492-501.
Neuman, S.P. 1994. Generalized scaling of permeabilities: validation and effect of support scale. Geophysical Research Letters 21:349-352.

Ovalle, C. 1994. Características ecológicas y la acción del hombre en el Secano Interior. p. 234. In Ovalle, C., and A. Del Pozo (eds.) La agricultura del secano interior. Instituto de Investigaciones Agropecuarias INIA, Cauquenes, Chile.

Rehfeldt, K., J. Boggs, and L. Gelhar. 1992. Field study of dispersion in a heterogeneous aquifer 3. Geostatistical analysis of hydraulic conductivity. Water Resources Research 28:3309-3324.

Rojas, R., O. Batelaan, L. Feyen, and A. Dassargues. 2010. Assessment of conceptual model uncertainty for the regional aquifer Pampa del Tamarugal-North Chile. Hydrology and Earth System Sciences 14:171192, doi:10.5194/hess-14-171-2010.

Rupp, D.E., J.S. Selker, and J. Šimunek. 2001. A modification to the Bouwer and Rice method of slug-test analysis for large-diameter, hand-dug wells. Ground Water 39:308-314.

SERNAGEOMIN. 1982. Mapa geológico de Chile. Servicio Nacional de Geología y Minería (SERNAGEOMIN), Santiago, Chile.

SERNAGEOMIN. 2003. Mapa geológico de Chile, versión digital. Servicio Nacional de Geología y Minería (SERNAGEOMIN), Santiago, Chile.

Sudicky, E.A. 1986. A natural gradient experiment on solute transport in a sand aquifer: spatial variability of hydraulic conductivity and its role in the dispersion process. Water Resources Research 22:2069-2082.

Sudicky, E.A., W.A. Illman, I.K. Goltz, J.J. Adams, and R.G. McLaren. 2010. Heterogeneity in hydraulic conductivity and its role on the macroscale transport of a solute plume: from measurements to a practical application of stochastic flow and transport theory. Water Resources Research 46, W01508, doi:10.1029/2008WR007558.

Thiem, G. 1906. Hydroligische methoden. Gephardt, Leipzig, Germany. 